\title{
Strategic Disaster Management in Indonesia: The Role of Muslim Societies through Islamic Da'wah Activity and Local Wisdom in Sustainable Management of The Environment and Disasters
}

\author{
Choirul Mahfud ${ }^{1}$, Nur Rofiq ${ }^{2}$, Muhamad Adlin Sila ${ }^{3}$, Rika Astari ${ }^{4}$, Amirul Mukminin ${ }^{5}$, \\ Firdaus Wajdi ${ }^{6}$, M. Arfan Mu'ammar ${ }^{7}$, Abdurrohman Kasdi ${ }^{8}$, Ahmad Munjin Nasih ${ }^{9}$ \\ \{ choirul.mahfud@its.ac.id ${ }^{1}$, nurrofiq@untidar.ac.id ${ }^{2}$, muhammad.adlin@uinjkt.ac.id ${ }^{3}$ \} \\ Institut Teknologi Sepuluh Nopember, Surabaya, Indonesia ${ }^{1}$, Universitas Tidar, Indonesia ${ }^{2}$, UIN and \\ Kemenag RI, Jakarta ${ }^{3}$, Universitas Ahmad Dahlan, Yogyakarta ${ }^{4}$, Universitas Jambi ${ }^{5}$, Universitas Negeri \\ Jakarta $^{6}$, IAIN Kudus ${ }^{7}$, Universitas Muhammadiyah Surabaya ${ }^{8}$, State University of Malang ${ }^{9}$
}

\begin{abstract}
Indonesia is well-known as the most vulnerable country to disaster and environmental problems than other countries. Some call Indonesia a catastrophic supermarket. This article uses qualitative data and methods to elaborate the relationship between Islamic da'wah and local wisdom in the sustainable management of the environment and disasters. Data obtained from various sources related to environmental issues and local traditions with Indonesian society's traditions. This research founded that the meeting point between Islamic da'wah and environmental issues is one of the strategic topics to support environmental management for disaster management adapted to each region's local culture. This paper also explains the importance of local wisdom considered in environmental and disaster management. Almost every area in Indonesia has unique ways when interacting with nature and the environment. Local understanding as a form of ecological preferences in community life has an essential role in building preparedness for facing natural disasters and rearranging sustainable environmental management.
\end{abstract}

Keywords: Muslim Societies, Disaster, Environmental Management, Local Wisdom, and Islamic Da'wah.

\section{Introduction}

Environmental issues, Islamic da'wah, and local wisdom are exciting topics to look at religious and ecological relations. Indonesia is a country with diverse cultures, religions, and local understanding in interacting with and overcoming disasters. There is a role for local wisdom and Islamic preaching in anticipating disasters [2], [3], [21]. In this context, Muslim communities' parts through Islamic da'wah activities and local wisdom need to hide more details in disaster resolution and disaster recovery.

Disaster areas have a uniqueness in geography, geology, and social culture characteristics. Therefore, disaster mitigation is always design with these characters. Community involvement and the role of local wisdom are significant in disaster mitigation. Natural disasters, by some 
people, are sometimes associated with myths and legends whose truth cannot be justified in a common sense [9]. Along with public education progress, these myths and legends are increasingly disappearing [10],[17]. Islamic da'wah can provide an overview and general understanding of disasters and their mitigation efforts with a local wisdom-based approach. Thus the wider community can understand and comply with the rules of spatial obedience and right so that there is a harmonious relationship between humans and nature.

Many geographers can anticipate the inevitable disasters in Indonesia. There are several fundamental reasons that geographically, Indonesia is flanked by three large continental plates. The Indo-Australian plate flanks the south side, which moves relative to the north. The Eurasian Plate flanks the north side moving southeastward, and the Pacific Plate and the Philippine Minor Plate flank the eastern side moving westward. The three plates' meeting zone's location is along the west coast of Sumatra Island, the southern coast of Java Island, Bali, West Nusa Tenggara, and East Nusa Tenggara. Then, turn north to Papua, Banda Sea, Maluku, to North Sulawesi. This pathway is the cause of earthquakes where nearly 90 percent of the world's earthquakes are born from this pathway, and 80 percent of them are of moderate strength.

Indonesia has 129 active volcanoes that can erupt and cause tectonic earthquakes that have the possibility of a massive tsunami. Apart from tectonic plate collision lines, Indonesia also has other earthquake sources. Some active faults included the Semangko Fault in Sumatra that stretched from Aceh to Lampung. According to geologists, the most earthquake-prone areas of Indonesia are on the west coast of Sumatra Island. The geological condition of the west coast of Sumatra, the Eurasian Plate's meeting zone, and the Indo-Australian Plate caused the regions to experience earthquakes more frequently than other Indonesia areas. Aceh, West Sumatra, and Bengkulu are the most frequent area hit by the quake. Currently being hit by an earthquake, West Nusa Tenggara is one of the many archipelago regions spoiled by soil fertility, panoramic beauty, and a wealth of natural resources. However, behind that contained the danger and threat of geological disasters. Located in the ring of fire in the world known as the ring of fire, the path of growth and development of volcanoes that coincide with earthquakes' most active pathways in the world.

Analysis of geographic data from experts above helps Indonesia's communities be more careful and ready to deal with disaster mitigation. The importance of the cultural context, Islamic da'wah, and local wisdom is one thing that requires consideration in disaster management, particularly in Indonesia, where each region has a distinctive local culture. The condition requires a disaster management strategy tailored to each area's culture in handling disasters and communicating the disasters' risks.

A disaster management strategy that does not pay attention to the cultural context makes disaster management efforts less useful - for example, making an evacuation route in a village to deal with an earthquake. Some people did not want to follow the directions because they were not following their culture. Therefore, disaster experts need to collaborate with psychologists, sociologists, religion, and culture or experts in other fields who better understand how to approach the community. Various local approaches in disaster mitigation improve monitoring of potential and threats of natural disasters in Indonesia and encourage community resilience in disaster-prone areas through collaboration between multiple parties. 


\section{Methodology}

In general, this research is descriptive qualitative research that analyzes data exploratively. In this case, the object of study is analyzed through data collection procedures to data analysis related to the main topics of environmental management, disasters through local wisdom and da'wah activities carried out by the Muslim community in Indonesia.

\subsection{Data Collection Methods and Techniques}

Data collection is carried out in various ways and methods that are more appropriate to obtain relevant sources that can be used to solve the problems discussed in this study. The documentation technique is one of the dominant techniques used in data collection in this study.

\subsection{Data Analysis Techniques}

In this research, the data analysis technique used is based on qualitative analysis guided by four stages: data collection, data reduction, data presentation, and the final step is making conclusions and verifying data related to disaster management issues through local wisdom and Islamic da'wah activities in Indonesia.

\section{Finding and Discussion}

This article elaborates that the geological reality in Indonesia is like a disaster supermarket. Therefore, Muslim societies' contribution and role in responding to environmental problems need more attention [1], [18], [19]. Indonesia is known as the most significant disaster laboratory in the world. In the past few decades, we have witnessed various types of disasters that have claimed many lives and not material losses. It can also observe the impact observed in various spheres of life. Therefore, disaster management is not enough to only rely on one particular discipline. Systematic, comprehensive, and efficient handling is needed to prevent and overcome multiple natural disasters' adverse effects.

Currently, there are 148.4 million people exposed to the earthquake. This amount is two times the total population of Thailand. They live in areas prone to earthquakes. Indonesia is one of the world's most vulnerable to natural disasters. Official BNPB data states that, throughout 2014, there were 1,559 disasters. This number has increased again because disasters still occur today. Geological disasters are indeed tricky or even impossible to prevent. The possible solution is to estimate the potential of catastrophe with scientific studies in the field-assisted by equipment, laboratory analysis, disaster history, and answers from all parties, including Islamic da'wah's role in sustainable disaster mitigation management [4].

\subsection{Environmental-Based Islamic Da'wah Management}

Nowadays, environmental issues have become an exciting topic for Muslims in Indonesia. This article also discusses every efforts to develop Islamic da'wah management in Indonesia. In this case, to understand the development of Islamic da'wah, environmental problems, and sustainable disaster mitigation management are necessary to understand the definition of da'wah management. The term management is an effort to regulate and direct various resources, 
including man, money, material, machine, method, and market. According to G.R Terry, management is a typical process concerned with planning, organizing, implementing, and supervising the stated objectives' determination and achievement using energy and other resources.. Robert Kreitner defines management as the work process with and through others to achieve organizational goals in a changing environment. This process is centered on the use of limited resources effectively and efficiently. Munir (2009) describes the term management as a process applied by individuals or groups in coordinating efforts to achieve a goal.

The term of da'wah also needs to be comprehensively understood. According to Endang S. Ansari, the name of da'wah means to call, appeal, and invitation. While the meaning of da'wah in the terminological sense includes the following: first, Islam's delivery to humans. Second, the translation and implementation of Islam in all aspects of human life, including politics, economics, social, education, science, arts, family, and others. Today, Islamic da'wah activities need to be carried out by management principles. Efforts to develop da'wah management have a positive impact. In this case, the term development of da'wah management is used in objects of worship and used for several activities, including in sustainable disaster mitigation management - the core of the managerial activities of an environment-based Islamic da'wah organization. In general, Islamic da'wah activities are running effectively and efficiently when achieved is true [2]. Therefore, understanding the elements of developing Islamic da'wah management is an important step. The goal is to have a clear concept of thinking to achieve the right method.

Practically, Brey Agan suggests four main stages of application to manage Islamic da'wah management, namely: a. Environmental Analysis: That is an activity to find out the organization's internal and external conditions to reflect the organization's internal situation (strengths and weaknesses) and the organization's position is external (opportunities and threats). This result is a factual basis in developing strategic policies and decisions in Islamic da'wah's operation for disaster mitigation purposes. b. Formulation of strategies and tactics, steps in formulating this strategy need to pay attention to the vision, mission, goals, targets, design of work/ action programs. The expectations will be generated (output) for the object of Islamic da'wah (outcome). c. implementation of strategies that focus on organizational structure elements and empowerment of human resources, leadership, culture, and corporate functions. d. systematic control or evaluation, both quantitatively and qualitatively, which can be considered for Islamic da'wah development in the next stage.

George Terry also has four views about management, namely: (1) Planning, (2) Organizing, (3) Actuating, and (4) Controlling or POAC. There are choices for da'wah elements: missionary planning, da'wah organization, mobilizing da'wah, controlling da'wah, and evaluating da'wah. a. Da'wah planning: this stage starts from making Islamic da'wah material about the environment conveyed to listeners; b. Organizing da'wah; c. Mobilizing da'wah; d. Da'wah control, this stage attempts to regulate the event's course to go according to the planning; e. Da'wah evaluation: this stage is a feedback effort given by the listener after receiving the preaching message delivered.

The development of disaster mitigation management through Islamic da'wah can, of course, be able to use several offers, as mentioned above. However, more importantly, the development aspect can also see the opportunities and challenges of da'wah today to make the future predictions and the analysis result of the positive and negative impacts of environmental programs. Analysis of the opportunities and challenges of contemporary Islamic da'wah in the ecological field can use internet-based social media. Moreover, social media tends to be more easily accessible to Islamic da'wah messages. Including the millennial generation. The development of Islamic da'wah management for mitigation and anticipation of disasters in a 
sustainable manner also considers various aspects of geography, economy, local culture, education, politics, cultural, traditional-modern art through the mass media.

Lately, information and technology development has become very important in life aspects, so communication is also not negotiable and becomes an essential part of completing human life. The methods, facilities, and devices have developed in such a modern way that now the world seems to have no limits. Humans can relate to each other so easily and quickly. The effort to redevelop Islamic da'wah management in disaster mitigation also needs to be done together using many ways and technology-based media. One way is to develop communication and the dynamics of the era marked by the rapid development of information technology, such as Facebook, Twitter, Friendster, Plurk, blogs, Wikipedia, Social Networking, YouTube, and mailing lists e-mail, chat facilities, and many more [13], [17]. Some of these media can help improve communication, which was initially one-way and two-way to all directions.

Hermawan Kertajaya, a marketing communications expert, discussed very well that the vertical, top-down, and one-to-many communication approaches would be replaced by horizontal, bottom-up, and peer-to-peer approaches and many-to-many, which be called as a "New Wave" by Hermawan. From here, of course, the development of a way of Islamic da'wah based on fair and proper communication is essential. Of course, it needs to be supported by adequate facilities and resources. In this context, the function of communication in the development of environment-based Islamic da'wah is at stake. It could be the key to success in Islamic da'wah activities [6], [8], [11], [12].

In this context, we need to know that communication is the key to da'wah in interaction. In history, the beginning of the communication process takes place very merely starting with some abstract ideas or thoughts in one's brain to look for data or convey information, then packaged into a message. The message is then transmitted directly or indirectly by using language in visual codes, sound codes, or writing codes, making each other understand. Communication can also serve to clarify and inform preaching messages. In environmental-based Islamic da'wah activities, the consideration of the communication development must continue. For example, how is communication between institutions, religions, media, apart from internal? It is all done, but it needs to be improved. In short, contact is required so that there is no misunderstanding, and it is expected to know each other and cooperate in achieving the goal of Islamic da'wah activities in environmental issues.

In the perspective of culture and language, words must be adjusted where the communication takes place. Not all terms and wording can be applied everywhere. Words that mean happy, energetic cannot be used in areas where people are being overtaken by misfortune, for example. Sayings in everyday relationships certainly cannot be used when guiding a speaker on a formal talk show, for example. In this case, the place dramatically influences how we must choose the right words. Use down-to-earth ways of speaking with material choices that those around us can understand. It is useless to talk in the formal academic language if the audience cannot understand that. We also need to consider the local culture's values that live in the community where we discuss something, including a disaster [14], [20]. Errors by breaking through cultural values negatively will harm Islamic da'wah activities. The activities must tailor each facility and delivery method to intended and the message of Islamic missionary activities to convey disaster mitigation in Indonesia. Each facility and delivery method must be tailored to the intended and the message of Islamic missionary activities for disaster mitigation in Indonesia.

In Islamic da'wah activities about the environment, there are four Islamic da'wah techniques, namely: the method of oral preaching ( $d a$ 'wah bil lisan), the method of preaching with writing (da'wah bi al-qolam), da'wah bi al-hal, and silaturahim in the method of $d a^{\prime}$ wah 
bi lisan using the method of religious lectures and sermons. In the method of preaching bi alqolam, the way is by writing in magazines and publishing books. The method of preaching is by doing waste sorting and reforestation. The silaturahim method is to approach the family and the surrounding community by giving Islamic touches to their da'wah and incorporating environmental preservation awareness.

\subsection{Local Wisdom-Based Disaster Mitigation}

We argue that local wisdom is one way of thinking and living behavior on environmental matters in community life in a place or region that has an essential role in dealing with natural disasters and sustainable ecological management. According to Putu Oka Ngakan, local wisdom is a value system or living behavior of local communities in interacting with the environment in which they live wisely. Almost every region in Indonesia has a personalized approach to nature. Many biological activities are captured as a language by residents. For example, in the 2004 Aceh tsunami, the death toll in Simelue, Aceh, was relatively small compared to other regions, namely 44 people. The elders understand nature's language; when the sea recedes and fish flounder on the coastline, the disaster will hit. When a similar phenomenon occurs, the elders ask the population to climb to a high place.

While in other regions of Aceh, the phenomenon of sea "recession" and the tangle of dozens of fish on the beach is unique. Fun scattered. People pick up fish and stare in amazement at sea tides. Then not long ago, high waves hit the land. Various experiences explain that local wisdom can play an essential role in reducing the impact of disasters. However, over time, changes in lifestyle and modernization resulted in a lack of respect for local traditions and culture. Caring for local wisdom in reducing the impact of disasters is perhaps one of the quick and appropriate ways. The fusion of science and technology, coupled with the care of local wisdom, of course, produces something significant, namely how to encourage the community to be resilient in its ways .

The term of smong is an example of local wisdom owned by Indonesian people in anticipating natural disasters. Smong is versed in traditional children's games on Simeuleu Island, Nanggroe Aceh Darussalam, Indonesia, which indirectly tells about the tsunami disaster that had lasted before. Smong explained in the temple, if there is a shock and the seawater recedes, it is necessary to look to a higher place because it is a sign of the tsunami disaster. Several Indonesian media reported that the eruption in 2010 has local wisdom such as beliefs about mountains that make people believe certain things as signs of a disaster. In this case, the risk communication strategy has an essential role in changing people's views and understanding their risks if they do not immediately leave the disaster site.

Many geologists state that Aceh has a very high potential for natural disasters, incredibly natural disasters such as earthquakes. Geographically, Aceh is close to the continental plate's meeting to occur or shift the plate. Even since the 2004 earthquake and tsunami events, Aceh seemed to have never been lonely from the earthquake shaking. Therefore, it is appropriate for this matter to be of concern to all parties from any perspective. One of the things that can be a lesson for our community, especially those in Aceh related to natural disasters, is local wisdom or what we hear more often or read local wisdom. Local wisdom is a value or teaching or norm that the community has long embraced, and the instructions are in the local area relating to things that have a positive charge for the community to natural events. Aceh also has local wisdom with a relationship with natural events, namely natural disasters, such as earthquakes. Moments when the earthquake in Aceh occurred, one of the national television electronic media reported on local wisdom existed in the Simeulue community. 
The coverage discussed the community's responsiveness before the earthquake and the earthquake. It was reported that when pets in the form of buffaloes had gathered in one place far from the coast (this shows the occurrence of natural events), the community had anticipated. Post-earthquake automatically evacuates itself by finding a higher area. In the language aspect, the Simeulue people also have local wisdom with the smong vocabulary, which is about the same as the meaning of the word tsunami. Local wisdom can be an initial signal or sign for humans to think and read natural signs. Local wisdom is not the only accurate parameter for natural events, such as earthquakes. However, with local wisdom combined with modern anticipation, it will significantly minimize the number of fatalities if there is an actual natural disaster [7], [22].

Local wisdom is sticking out as an answer to the limitations of technology in anticipating natural events. Local wisdom is part of a strategy against capitalism [5]. The recent polemic regarding tsunami early warning that does not work effectively can be eliminated by strengthening or exploring the existing local wisdom and then transmitting the local knowledge to the community. The goal is to detect early the existence of natural events, such as earthquakes. It is known that Japan, which is a state with sophisticated technology, still uses local wisdom and is included in the curriculum in their schools.

We were learning from Japan's experiences in facing the earthquakes. We knew that Japan also has a high potential for earthquakes. People in Japan can anticipate an earthquake from natural signs in the form of clouds in the sky, like being attracted to a point. The cloud's shape is not like a normal state and tends to elongate like a line (not lumpy). Combined with scientific analysis from earthquake experts in Japan, this local wisdom considers clouds' wonders like this often appear in Aceh's sky. Maybe every time, we can prove or at least pay attention to natural phenomena in the form of clouds. Moreover, the cloud's shape is like being attracted to one point because of the gravitational force in the epicenter area, resulting in the cloud's shape.

Different from Aceh and Japan, also separate from Yogyakarta. When Mount Merapi erupts, communities around the mountain are familiar with natural changes, especially animal behavior changes. People around the slopes of Merapi often encounter wild animals that descend into their villages. Sometimes they meet or see tigers, bears, or snakes. The frequency of people who often see the "decline" of these animals becomes a hunch or sign that they have long believed that natural events will occur, namely those usually associated with the lava activity of Mount Merapi. It has become a belief for people who live around the slopes of Merapi.

Every community has local wisdom [13], [15], [19]. That will be a lesson if the local knowledge is extracted by its validity aspects, which can then be taught to the community so that early anticipation is done faster if natural events occur in earthquake disasters and others. Local wisdom is collective learning integrated with modern forms of natural disaster response learning. The more local wisdom is explored and taught to the community, it is not impossible that preparedness and disaster response conditions in the community will also be better. The disaster awareness culture is often associated with the strength of local traditions. Customs will be required to inhibit disaster mitigation. However, in some ways, local wisdom about human and natural relations can be based on disaster mitigation in the modern era.

In this context, we argue that the government and other institutions' efforts to help manage and reduce disaster risks that the community faces must respect the culture, traditions, and local wisdom they have. It has also been proven in Aceh, especially in Simeleu, where people rushed to save themselves to hilly areas when there were earthquakes accompanied by tsunamis so that there were only a few victims compared to other regions with tens of thousands of victims. The extension model will involve insiders to help provide new knowledge and make changes that 
can reduce suspicion. The solution to making changes at Islamic boarding schools in Madura was that the campus gave scholarships to 18 Gus. When they go home, they can make changes in their pesantren. If we come directly to the pesantren, it will be difficult. So what is needed is participatory leadership, not coordinating. They are not given enough modules tips on efforts to empower Islamic boarding schools.

The pesantren-based disaster risk reduction module needs to be prepared and expected to guide pesantren that often references the surrounding community in a disaster. The religious approach, rather than the scientific approach, is also the key to empowering the pesantren community. It was proven by the involvement of clerics in the implementation of family planning (KB). The method uses the argument that we should not leave weak offspring. The use of the religious approach and local wisdom seems to have succeeded in greening Madura's bare hill. Teaching the community to plant trees is a charity and will be rewarded as long as it is still alive. In handling disasters, donors are required to read the priority scale carefully. From observations during the earthquake in Yogyakarta, the people were more appreciative of making waterways from a non-Muslim group than the establishment of mosques by an Islamic party.

The role of pesantren in carrying out cultural transformation is quite useful [10]. Understanding Muslims who still consider ritual worship to be more valuable than social worship is also a cause of Muslims' lack of development. Twenty percent of pilgrims are people who repeat their hajj. If they want to allocate the 500 billion funds used for Islamic education, the results will be extraordinary. It has also occurred in the construction of mosques and hospitals. The community considers contributing to the establishment of a mosque as temporary worship to build a hospital. The value of worship is less, especially for the establishment of a bank. The understanding of ritualism that is still ritualistic also causes people not to understand the risk of disaster. Tuban's area is up to Gresik, predominantly Muslim, but its coastal conditions are threatened with abrasion. People still think that saving the environment is not part of worship .

In West Sumatra, the Gadang house symbolizes local wisdom in the face of floods, earthquakes, and tsunamis. The Gadang houses or big houses are not only in physical terms but also in their functions and roles related to adat and preparedness in the face of disasters. The home of residence in Minangkabau is known as the Gadang house. The ship-shaped Gadang house pattern with a roof has a curved ridge up to about half a circle. The floor plan is rectangular, and the floor is above the poles. The stairs to enter the house are in the middle. He explained the Gadang house was built with a height of about three meters above the ground with its large poles. Installation of strong pillars and floors three meters high from the ground is useful for avoiding disasters. The non-Gadang house is also helpful to evacuate by climbing poles to the roof in a flood or tsunami.

During the past 300 years, Rasmi explained that an earthquake and tsunami hit the West Sumatra coastal area. At that time, the Gadang house was beneficial as a means of evacuating residents. The Gadang house is also equipped with emergency stairs installed near the window. Local wisdom like this is certainly essential to continue to be maintained to minimize casualties when natural disasters occur. In Bali, water management initiatives come from the community, especially farmers. Uniquely, this system is not only in the form of infrastructure but also in a social network. As an infrastructure, subak functions to facilitate irrigation. To ensure that water is distributed evenly and resolve the water dispute, the farmers consult. Rembukan is also called subak. The organization of irrigation water management has been around for a long time. Based on archaeological data, especially epigraphy data, this organization was at least known in Bali in the 11th century, during King Anak Wungsu. 
The Samin community in Blora, the border between Central and East Java, also has initiatives to manage water. The method is simple. They do not make various buildings for water management. Management was born from their universal view (weltanschauung): taking enough natural produce and, for example, using river water. Communities may not exploit water for sale. The important thing is that life needs are met without destroying nature. This view comes from Samin Surosentiko, a citizen of Blora born in 1859. He developed kebatinan (spirituality) teachings. Later his followers are called Samin people. They prefer to be called wong sikep (responsible person). Nature for wong sikep is a gift, and they are reliable. This view is sustainable until now. So, when there was a cement factory plan to stand in their area in April 2012, Wong Sikep refused because it is afraid that it will damage the environment.

The Baduy showed a similar attitude in Banten. Until now, they refused to exploit nature by investors. They lived for centuries in the Kendeng mountain. They are friendly with nature and keep their environment sustainable. Their presence was recorded for the first time by CL Blume, a German botanist, in 1822 . We have several original villages, which deliberately hide from the eyes of outsiders. In the darkness of the dense forest, they could still worship their gods for centuries. To protect the environment, they apply several methods. They cut down the forest to make fields, but there was never a fire disaster. They have the knowledge to choose the land that is suitable for human rights. They know the type of soil, humus content, and slope. They have acquired this knowledge from generation to generation. This conservation method is also applied in the construction of dwellings and the management of water and other crops. Evidenced through its local wisdom, the Baduy people can prevent disasters, both in the tradition of cultivation, traditional buildings, and concerning forests and water.

The Baduy community also knows the concept of prohibited forests. People usually call it a "haunted forest." Let alone cut down; people cannot just enter the forest. There is a ritual and a particular time to enter there. They believe ancestral spirits are still residing. Inadvertently entering, a disaster can come not only in the Baduy community. This concept is traced to many places in the archipelago. Restricted or holy forests are not limited to Java. It also existed in Sumatra, Bangka, Kalimantan, Buru, Bali, Sumba, and Timor. The Baduy community is one of Indonesia's tribes that still maintains its fundamental cultural values and beliefs. Many Baduy people currently inhabit the Kendeng Mountains in Lebak Regency, Banten. In responding to an earthquake, Suparmini described that the Baduy community worked around this by making adat or pikukuh rules and prohibitions in building houses. In this case, the building materials used are flexible materials, such as bamboo, palm fiber, and the house is not easily damaged. The home must also not be established directly touching the ground. It is done so that the house does not easily collapse.

The same thing happened in Bali. Earthquake mitigation carried out by Balinese people is classified as spontaneous action carried out down and down. Spontaneous action is grouped into four types: seeking protection, telling others, conveying one's situation, and asking for protection from the Almighty God. People of ancient times knew the area was prone to earthquakes. Therefore, they build a house with a simple mindset with earthquake-resistant building designs. Traditional buildings made of bamboo or wood are generally not damaged by an earthquake because they have a flexible nature against shocks. The building foundation, pole ties, and pegs on the wood are arranged to be flexible during shocks. This local wisdom is now unconsciously being abandoned by the community [16]. The house building was made of brick or concrete for imaging the modernity. They only consider the aesthetic aspects without regard to the security aspects, such as areas with earthquake swamps.

In the matter of awareness and anticipation in the face of disaster, Japanese society is very worthy of being an example. In Japan, for example, socialization and training to deal with 
earthquake disasters are continuously carried out periodically. Also, infrastructure and buildings have been designed so that it is very safe when an earthquake occurs. Even small things have been taken into account. A controller to turn off the gas line at home, for example, has been calculated placed under the table. Thus, when an earthquake occurs, the table's bottom becomes a refuge place while turning off the gas flow not to ignite a fire. In Hokkaido, Japan, there is always a park in a higher position in every settlement block. The location was made a safe zone when the earthquake occurred and caused a potential tsunami. If there is a tsunami hazard warning, everyone knows they have to run to the park. In Indonesia, disaster preparedness is still un-preparedness. Many local governments have not prepared to deal with disasters and face emergencies. We always behave like firefighters that come only when a disaster strikes. It is necessary to have all social levels' participation in bringing about a culture of safety from disasters. In this context, Indonesia's local wisdom can become a platform for Indonesian cultural heritage that supports more participatory and comprehensive environmental management.

\section{Conclusion}

Sustainable environmental management based on local religion and culture requires synergy and cooperation between all societal elements in Indonesia. The contribution of religion and local culture should not be underestimated. The role of kyai, ustadz, and religious leaders in effectively delivering Islamic da'wah will influence the community's understanding of environmental problems and disasters. Local wisdom in line with Islamic proselytizing proenvironment messages needs to be appreciated and developed to sustain the environment sustainably.

Acknowledgments: The authors gratefully acknowledge ITS Surabaya and Universitas Tidar for supporting the research collaboration. Additionally, we would like to thank the reviewers and publisher for giving us a chance to publish our article.

\section{References}

[1] Ali, Abdullah Yusuf. The Meaning of the Holy Qur'an. Beltsville: Amana Publications, 2002.

[2] Athoillah, Anton. Dasar-dasar Manajemen. Bandung: CV Pustaka Setia, 2020.

[3] Azra, Azyumardi. The Origins of Islamic Reformism in Southeast Asia. Honolulu: University of Hawai'i Press, 2004.

[4] Boggs, Carl. Ecology and Revolution: Global Crisis and the Political Challenge. New York: Palgrave Macmillan, 2012.

[5] Foster, John B., Ecology against Capitalism. New York: Monthly Review Press, 2012.

[6] Haedari, A. Masa Depan Pesantren Dalam Tantangan Modernitas dan Tantangan Kompleksitas Global. Jakarta: IRD Press, 2014.

[7] Isbah, M. Falikul, Pesantren in the Changing Indonesian Context: History and Current Developments, QIJIS, Vol 8, No 1, 2020.

[8] Krisdiyanto, G, Muflikha, Sahara, Mahfud, Choirul. Sistem Pendidikan Pesantren dan Tantangan Modernitas. Tarbawi: Jurnal Ilmu Pendidikan 15 (1), 2019: 11-21. 
[9] Lukens-Bull, Ronald A., Two Sides of the Same Coin: Modernity and Tradition in Indonesian Islamic Education. Anthropology and Education Quarterly. 32, No. 3, 2001.

[10] Mahfud, Choirul. Chinese Muslim Community Development in Contemporary Indonesia. Studia Islamika, 25(3), 2018.

[11] Mahfud, Choirul. The Role of Cheng Ho Mosque, JIIs, 8.1, 2014: 23-38.

[12] Mahfud, Choirul. Imagined Islamic Societies and the Role of Ulema in Contemporary Indonesia. Akademika, 24 (2), 2019a: 269-278.

[13] Mahfud, Choirul. Tantangan Global dan Lokal Islam di Indonesia. Yogyakarta: Penerbit Samudera Biru, 2019c.

[14] Mahfud, Choirul, et.al, Islamic cultural and Arabic linguistic influence on the languages of Nusantara: From lexical borrowing to localized Islamic lifestyles, Wacana, Vol 22, No.1, 2021.

[15] Maksum, Ali et. al. 2020. Ideological Conflicts Between Radical and Moderate Islamic Organizations in Indonesia, JTDE, 12 (1), 2020: 2248-2261.

[16] Mukminin, Amirul. Habibi. Promoting Access and Success for Disadvantaged Students in Indonesian Basic Education: Handbook of Research on Social Inequality and Education, 2019: 403-413.

[17] Muyasaroh, Mahfud, Choirul, et al., The Utilization of Gadget in Maintaining Prophetical Values in Millennial Generation, IJPR, 24/ 4, 2020: 5602-5615.

[18] Nasr, S Hossein. Man and Nature; the Spiritual Crisis in Modern Man. London: Allen and Unwin, 1968.

[19] Nasih, Ahmad Munjin, and Mahfud, Choirul, et.al, Islam and Culture in Southeast Asia, Sciendo, 2020.

[20] Suyadi, Z Nuryana, et.al. The Fiqh of disaster, International Journal of Disaster Risk Reduction, 101848, 2020.

[21] Wahyudi, Deni, Human responsibility towards the environment in the Quran, IJIMS, Vol 2, No 2 (2012)

[22] Yusmaliana, Desfa, and Widodo, Hendro, Reconstruction of Islamic Education Curriculum in The Disruption Era, IJISH, Vol 2, No 1, 2019. 